\title{
The Narrative of Ethnic Minority Children on Education in Central Java - Indonesia
}

\author{
HAPSARI DWININGTYAS SULISTYANI \\ TURNOMO RAHARDJO \\ LINTANG RATRI RAHMIAJI \\ TAUFIK SUPRIHATINI \\ Universitas Diponegoro, Indonesia
}

\begin{abstract}
Education is a significant narrative to develop society. Any developmental effort that targets local people should take into account the local education system in place, which has been passed on from one generation to another. Comprehending local children's narratives on education is crucial for formulating an education method that incorporates both formal educational principals and local educational practices. The central locus of this research is to explore how the children of Sikep -- an ethnic minority group in Indonesia that has a specific perspective on education and social values -give meaning to the discourse of education. There are six informants in this study. They are Sikep children from Baturejo Village, Pati Regency, Indonesia. The research used in the study is an ethnographic approach made by employing qualitative interviews and observing the life of the Sikep community. The findings signify that the Sikep children have a specific narrative on education. Such narratives determine their interpretation of the education process in their daily lives. There are specific principles of learning held by the Sikep children such as the parents are the main teachers, learning agricultural works in their daily lives as a part of the hard-skills requirement, and practicing local values of morality and spirituality as soft skills. The narrative of the Sikep children on education suggests that school as a learning process in their daily lives cannot be replaced by the formal school. Hence, the education process which accommodates the local values is necessary to increase the Sikep children's participation in formal school.
\end{abstract}

Keywords: Children narrative, ethnography communication, ethnic minority, education, sikep.

\section{INTRODUCTION}

Children's education is an important and essential issue in any community. Educating children involves cultural and social considerations. The objective of children's education is to teach them to become more advanced in terms of their knowledge, aptitude, emotion, and social connection, and morality (Rasna \& Tantra, 2017). The government of Indonesia is implementing a national education program that applies to all school-age children across the country. However, the government's efforts to implement a universal education system cannot be taken for granted. As consequences of various traditions, cultures, and geographical conditions in Indonesia, there are numerous teaching methods and areas of learning considered significant. Sikep is one of the indigenous communities in Indonesia that has a specific and unique way of life. They hold a principle of life in which a legacy shall be passed on to their descendants. They ensure that a legacy such as values and way of life is inherited by a special traditional education for their children. In other words, the Sikep children have education which is different from that of children outside the ethnic group. This places Sikep children in the dilemma of choosing between two educational systems -traditional educational system and formal educational system implemented by the 
government - which affect their life. According to Kennedy and Hue (2011), students from ethnic minority groups tend to be invisible to the policymakers. The government mainly focuses on developing the educational system for the majority and downplay the notion that the system creates participation barriers for the ethnic minority children. This research analysed the narration about education of Sikep children belonging to a community that has two different education concepts, which are even contrary to each other.

Rosyid (2010) states that the Sikep community, in reality, is forbidden to send their children to formal school. The Sikep community members may only be educated by their parents themselves (informal). The material taught is the basic principles of social ethics and skills to become a successful farmer. Many of the Sikep people think that formal school is merely beneficial to learn how to read and write. Subjects other than learning to read and write is not useful because it does not provide knowledge of farming. Being a farmer is the only occupation considered good by the Sikep community. In addition to farming, Sikep people need to learn and understand the Sikep philosophy of life. The values of goodness firmly held by the Sikep community are universal. However, they are extremely serious about it without any room for negotiation.

According to Alamsyah (2015), some values which must be followed by members of the Sikep community are: they must not accuse another, must not steal, must not take anything natural without any obvious reason (such as, picking any leaves on the roadside without any particular reason), must not take other's belongings that have become market commodity, and must not take items whose ownership is not clear. Such values are extremely implemented without compromise and are not flexible with the surrounding circumstances of society. The way in which Sikep people implement their extremely-held values has led them to being seen as a group deviating from dominant social values.

The unconventional concept of education and life philosophy has made it difficult for the Sikep children to have access to and to adapt themselves to formal education. The difference between Sikep's educational values and formal education has caused low participation of Sikep community members in formal education. This research describes the narration of education on the part of the Sikep people living in the Baturejo Village, Pati Regency, Central Java. The monographic data of the village shows that the education level in the village is relatively low.

Table 1: Education Level of Baturejo Villagers

\begin{tabular}{clcc}
\hline No & \multicolumn{1}{c}{ Education Level } & $\mathbf{F}$ & $\mathbf{\%}$ \\
\hline 1 & Academy/University Graduates & 35 & $1.51 \%$ \\
2 & Senior High School Graduates & 190 & $8.21 \%$ \\
3 & Junior High School Graduates & 452 & $19.53 \%$ \\
4 & Primary School Graduates & 894 & $38.63 \%$ \\
5 & Not Completing Primary School & 99 & $4.28 \%$ \\
6 & Studying in Primary School & 223 & $9.64 \%$ \\
7 & Not going to school & 421 & $18.19 \%$ \\
& Total & $\mathbf{2 3 1 4}$ & $\mathbf{1 0 0 . 0 0 \%}$ \\
\hline
\end{tabular}

The data shows that the majority of Baturejo Villagers graduated from Primary School (38.63\%), and Junior High School (19.53\%), whereas the number of children who do not go to school is also high (18.19\%). This is because there are two areas in the village of Baturejo, where the majority of residents are Sikep people. Most of Sikep community members do not send their children to formal school, and if any, their number will only be 3-4 in the local school. On average, they do not graduate from primary school. The Sikep people who allowed 
their children to go to formal school are those who partially follow the Sikep way of life or those who married people outside the Sikep community. In other words, the participation of Sikep people to attend formal education is very low. In addition to low participation in formal school, becoming a farmer is the only option for the Sikep people. Monographic data of the village shows that most Baturejo people work as farmers as can be seen in the following table:

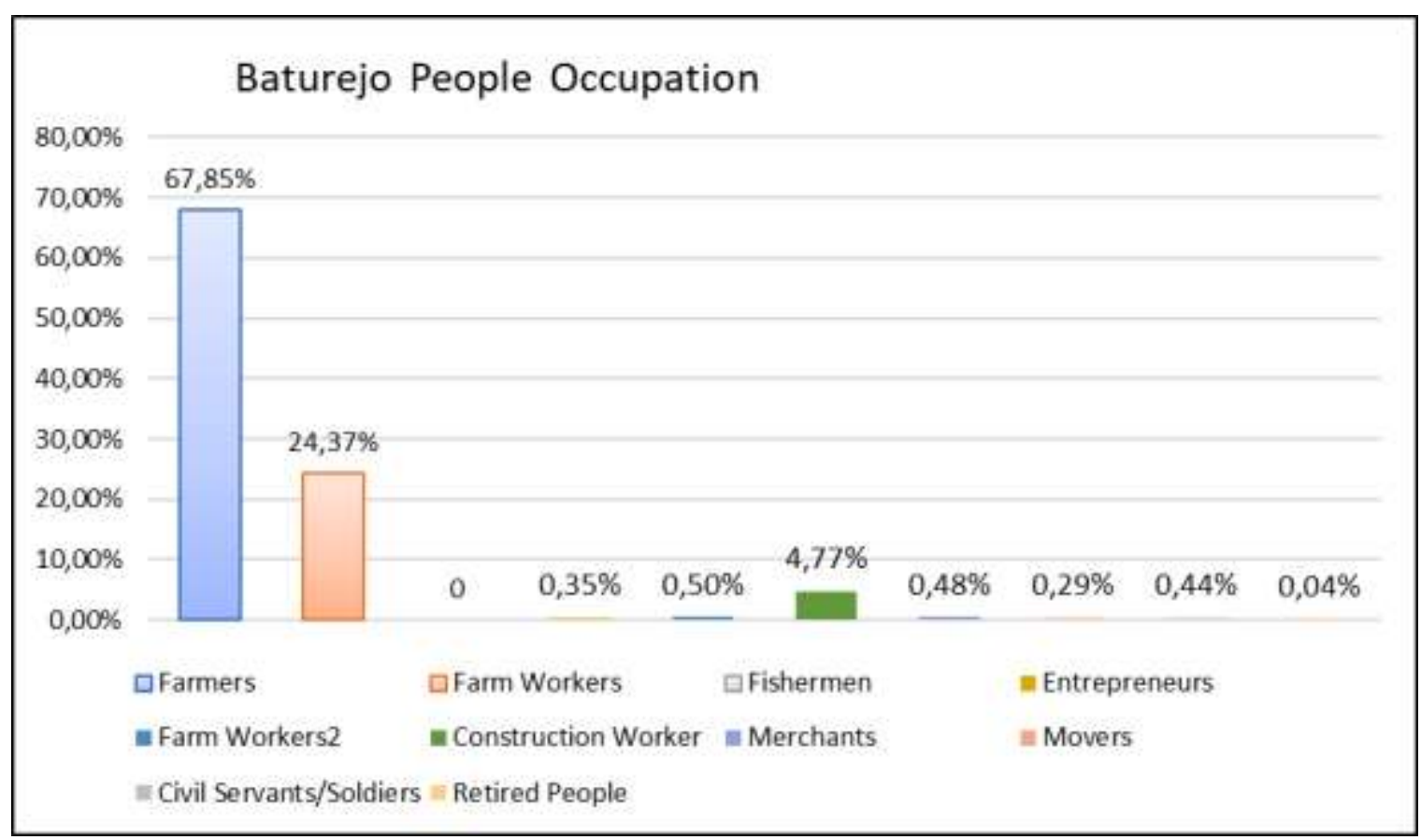

Figure 1: Baturejo People's Occupation

The data shows that the majority of Baturejo people work as a farmer on their own land $(68.75 \%)$ and some others work as a farmworker $(24.37 \%)$. The orientation of their thoughts to become a farmer is not considerably supported by the learning subject in formal school. The school funded by the government does not provide room for the Sikep children to study farming and practice Sikep people's belief. The situation has caused the Sikep children to be considered deviant. According to Meon and Tojerow (2019), particular minority groups have experienced discrimination in educational environments. In particular cultures, for example, the teachers tend to grade the children from marginal groups lower than the children from the dominant group. The situation may be extended to students whose religious belief is discredited (Meon \& Tojerow, 2019). This research proposes the need to analyse the narration of Sikep children on education. Research findings are expected to deliver an in-depth knowledge of Sikep children's perception of their experience in traditional education as well as to describe the narration of Sikep children attending the formal school. This research presents the voice of Sikep children to consider the most relevant education system for the Sikep children.

\section{LITERATURE REVIEW}

Sikep people are a community that has a specific way of life. Therefore, it is important to develop a synergy education model that combines the formal education system and local wisdom. Previous researches had been conducted to explore local wisdom in the Sikep community. One of the researches was conducted by Rini Darmastuti et al. (2016), "Gethok 
Tular, a Communication Pattern of Social Movement based on Local Wisdom of the Sikep People in Sukolilo, Pati Regency." This research focused on social movement which refuses the planned development of a cement plant in the Sukolilo Sub-District, Pati Regency described as a unique social movement. The movement, known as anti-action, was held peacefully. The objective of Darmastuti's research was to find out if there is any social communication pattern based on the local wisdom of the Sikep people in the Sukolilo District. Sikep is a community that realizes the importance of communication.

One strategy used in the anti-action movement is communication strategy. Based on their local wisdom and Java culture, which emphasizes harmony and coherence by the peaceful and respectful community, the gethok tular is a strategy used in the movement. The Gethok tular is an informal communication strategy with a personal approach. The research is important because it shows how the local values of the Sikep people can be used to overcome any problem currently developing in the Sikep community. Another previous research that specifically linked the Sikep people's perception to the government program was conducted by Suprihatini in 2016. The research focused on Sikep people's perception of health programs which showed that the Sikep people had cultural barriers that prevented them from participating in the government program. The socialisation of Family Planning and immunization, for example, did not receive a positive response. The cultural wisdom which perceives "the more children the more wealth" has led to low participation in family planning programs. Suprihatini research shows that the government programs were responded negatively by the Sikep people because the socialisation is carried out notwithstanding the values held by the Sikep people. Thus, Sikep people's local wisdom is an important subject of study before the implementation of government programs in the Sikep community.

A research on Sikep local wisdom was conducted by Alamsyah (2015) Existence and Wisdom of Samin Community in Kudus and Pati. The research shows that the Samin or Sikep is not a new community, it is a community that has existed since the late 19th century in Blora. From Blora, this community spread out to several regions including Kudus and Pati. The existence of Sikep's philosophical beliefs until its establishment as the Sikep community was promoted by the figure (botoh) of Samin. This botoh visited many regions using a communal strategy. The central figure of Samin was Raden Kohar or Samin Surosentiko, a noble person who preferred to live with common people and resisted the Dutch colonial ruler. Currently, the perception of some people who perceived the Sikep group as being "deviant" has become an issue owing to poor knowledge and understanding of the Sikep community. In reality, this community has many local pearls of wisdom such as peaceful life and nature preservation.

The local wisdom of people can be observed from their speech codes which only applies to the community. Some research have been conducted on the tradition of Speech Codes theory, of which substance can be divided into three research groups (Miller, 2005). First, researchers focus on describing the speech codes of a particular cultural community. The study of this first group is about one or several important records on special aspects of the cultural community under investigation. An example of this research is Eric Aoki's study in 1996 that recorded themes such as; labor, religion, and family in the speech codes of a Mexican community in America (Aoki, 2000, Miller, 2005). Second, researchers compare the speech codes within different communities. Research by Carbaugh in 1990 tested the interaction in a television show the Donahue by comparing the US speech codes with the Soviets when it comes to talking about "self" (Miller, 2005). Carbaugh analysis in 1990 indicates that the Soviet people emphasized dichotomy between public and private life in comparison to the US people (Carbaugh, 2008). Third, several types of research on speech 
codes are used to understand certain speech codes to argue on universal verbal principles (Miller, 2005). The research on the Sikep children's narration on education is related to the first research group because it analysed unique and important thematic topics in the Sikep community on education.

The research of Sikep children's narratives on education uses the paradigm of Critical Constructionist. This research does not refer to the universal value or any effort to change a predominant structure. The critical constructionist argues that our mindset on an issue within a community had been distorted by the authoritative relationship in society (Heiner, 2006). Therefore, critical constructivism study social and political bias of power relations in the dominant discourse. Critical constructivist mainly questions the logic of thinking that constructs the dominant social actions in a particular cultural group (Steinberg, 2014). In other words, critical construction researchers examine the power relations that shape the logic of oppression experienced by a particular cultural group in society.

Critical construction researchers also focus on how dominant knowledge is produced in society. The process of understanding is carried out through in-depth descriptions. The thick description is conducted by studying important factors in society such as social, economic, social psychology, and culture (Steinberg, 2014). Critical construction researchers mainly focus on comprehending how the dominant logic of thinking in a society that can lead to the privilege of certain people and oppress others is formed (Steinberg, 2014). The research which uses this mindset is oriented to the understanding and criticism of predominant belief held within a social arena.

Philipsen (in Chornet \& Bracey, 2017) prosed a Speech Codes Theory (SCT) which argued that communication is a specific local activity that happens and is directed by the uniqueness of a community's culture of indigenous people or often called speech codes. Speech codes of a community are shared by individuals, understanding each other, and local communication practices. Communication activities of a community creates community boundaries. The SCT is closely related to ethnography research which describes various local verbal and dialog to create specific meaning within the local cultural context. Speech codes of a community may be used to understand the way of life, values, and the specific culture of a community. Simmons (2013) argued that the SCT is an important tool which enables the interpretation of respected values in a specific ingenious people. The SCT is based on communication ethnography capable of providing a thorough and rich description of a specific group, including the children group who lives in a community. Hart (2017) states that the speech community often has specific codes that they are often unaware of. This study examines the Sikep children's narratives about education so that the code of honor, the code of logic, and the code of spirituality inherent to the Sikep community can be understood.

\section{METHODOLOGY}

The research method used is critical ethnography. According to Michael Quinn Patton (2002), an ethnographic study can be seen as an "orientational" study if its onset assumption stated cultural centrality to explain human actions. Critical ethnography non only concentrates on understanding a particular cultural group way of life but also commits to using its findings for advocating changes for the oppressed or marginal group. Orientational qualitative analysis is a significant method for ideological and theoretical underpinning, verification, and explanation. The researcher highlights the gap of authority between groups in the community. Most cultural critical ethnographic researchers study dominant class and 
ideology and the struggle nuance of various oppressed groups. Most of them have an in-depth commitment to bring forward equality in the people and some aspire to create universal theoretical knowledge and local practical knowledge.

A critical ethnographic researcher focuses on the ethical responsibilities to fight injustice in a particular marginal group or community and believes that the ethnography research should be conducted as an effort to challenge the status quo (Madison, 2020). This research focuses on listening to the narration of Sikep children on education. According to Kim and Covino (2015), children compose their narration by having a conversation in their daily life. Children also compose narration when they interact with one another. Observation of time and space in children's daily life will signify the narration which corresponds to each other from the children's perspective on education. Narrative practice is a cultural practice that represents the children's repertoire on their learning experience (Kim \& Covino, 2015). Jessica Shaw (2017) also argues the importance of using the language and utterance for analysing the logic of a particular living narrative.

Thus, this research uses narrative data collection and ethnographic data analysis collaboratively that include observation, interview, testimonio, and narrative description. The researcher conducted observation and directly got involved in the daily life of the Sikep children, such as when they were learning at school and at home. The researcher also tried to form a close relationship with public figures and parents of the Sikep people. Therefore, they could help the researcher build the perspective of "internal" education which emphasizes how the children give meaning to their current education. The researcher then openly interviewed the Sikep children to share their experiences in school, either formal or traditional.

Testimonio is a data gathering for listening the utterances of marginal people's repressions (Chase, 2018). In this research, the testimonio method is used to understand the narratives of Sikep children who live in a conflict between predominant education concepts or formal education implemented by the government and local discourse of education implemented by their tribe and parents. The Sikep children live in the middle of power between the two different concepts. Hence, this research will explore the voice or acknowledgement of the children learning the experience.

The results of observation and interview are presented in the form of a detailed transcript and are then analysed to find the meaning themes such as those correlated to the speech codes on education. After the children's meaning of education has been formed, each of the themes will be described for its narration logic by means of interpretation process. Narrative description provides a comprehensive and detailed overview of the education context in the Sikep people. Such a social context overview is important as a means of interpretation to form specific narration of the children in relation to the learning process. The narrative description gives a detailed overview of the education narration of the Sikep children. Therefore, people outside the Sikep community can understand the perspective, logic, and social arena, including the education concept of the Sikep people.

\section{RESULTS AND DISCUSSION}

This research examines the children's verbal communication in education. The informants who participated in this research are six children from the Sikep community, comprising three who go to formal school and three who do not go to formal school. The first three informants are primary school students, while the last three informants fully rely on the Sikep community education where their parents teach them all philosophies of life and skills needed to sustain 
the Sikep community. All the informants in this study are at the elementary school age. There are three important parts included in the findings, namely Sikep children's narration on education, teacher narration on the Sikep children, and the narration of daily life of the Sikep children.

\section{The Narration of Sikep Children on Education}

As a consequence of the difference of education methods, the narratives of the Sikep children who go to formal school will be different from those of the Sikep children who do not go to formal school. The following table shows the differences between the two kinds of narratives from the two groups of informants. The narratives are divided into four themes: material learned, learning place, learning result (future dream), and educator.

Table 2: Sikep Children Narrative on Education (School)

\begin{tabular}{|c|c|c|}
\hline \multicolumn{3}{|c|}{ Sikep children's narrative on education (school) } \\
\hline $\begin{array}{l}\text { Narrative } \\
\text { themes }\end{array}$ & Sikep children who go to formal school & $\begin{array}{l}\text { Sikep children who do not go to formal } \\
\text { school }\end{array}$ \\
\hline Areas of Study & $\begin{array}{l}\text { At school: learning a particular subject } \\
\text { such as reading, a particular, religious } \\
\text { study, writing, math, and languages. } \\
\text { At home: learning agricultural skills and } \\
\text { Sikep's moral principles. }\end{array}$ & $\begin{array}{l}\text { Learning agricultural skills (farming, fishing, } \\
\text { and homesteading) and Sikep's moral } \\
\text { principles. }\end{array}$ \\
\hline $\begin{array}{l}\text { Locus of Study } \\
\text { and Learning } \\
\text { Experiences }\end{array}$ & $\begin{array}{l}\text { At school: learning obediently } \\
\text { At home/farms/homestead: learning as a } \\
\text { part of daily life. }\end{array}$ & Daily life learning experiences \\
\hline $\begin{array}{l}\text { Education } \\
\text { Outcome }\end{array}$ & $\begin{array}{l}\text { Future profession: teacher, police, pilot, } \\
\text { etc }\end{array}$ & Future profession: farmer, homesteader \\
\hline Educator & teachers at school and parent & Parents \\
\hline
\end{tabular}

The first theme is the area of study comparing materials learned by children who go to formal school and those who go to traditional/Sikep school. The Sikep children who go to formal school feel they go to school at two places, namely formal school whose locus is at the primary school and traditional school whose locus is at home. Sikep children who go to formal school must study all subjects covered in the national curriculum, such as mathematics, citizenship, and religion. According to King (2015), the formal school and its curriculum including the textbooks are usually used to maintain and naturalize the oppression of minority groups in society. The minority must adopt the dominant way of thinking to be accepted in the dominant society.

The Sikep traditional community has an education concept that teaches their children morality principles and skills required to become a highly dedicated farmer. The Sikep children who are enrolled in formal school are also taught such subject matters as traditional norms and farming skills needed in their daily life. On the other hand, the Sikep children who do not go to formal school focus on the Sikep traditional education in which materials cover farming skills and aboriginal lessons related to the Sikep morality principles that ban community members from stealing, taking other people's rights, being jealous, being evil, and being embroiled in a conflict with another, among others. Such materials are learned in daily interactions. Following is a narrative from informant $\mathrm{S}$, a Sikep child who does not attend formal school. 
"Kulo niki nggih sekolah. Sekolah kulo teng pondokan. Kula pengin dados tani. Sakniki kulo sampun sinau tandur pari kaliyan ndaud." (I am a student too. My school is at home. I want to be a competent farmer. My parents teach me how to plant rice and sow seeds).

The Sikep children still hold a perception that the main purpose of going to school in their community is to learn how to be a farmer. The Sikep people have farms they inherited from their ancestors. Even though their crops have often failed because of vermin (bugs, rats) and flooding, they never give up to plant rice. Once in a while, they also plant corn and fruits (melon, watermelon, cantaloupe).

According to the research informants, the rice-planting skill must be possessed by all Sikep children, both boys and girls. Another skill that they must have is to make tools to work, including a fish-catching tool using battery. The fish is stung with electricity thus, it can be caught more easily. Almost every night, Sikep boys go fishing using a tool they have made themselves. This suggests that the Sikep people can actually accept technology to help earn their livelihood according to their tradition. Fisinhing and farming is natural livelihood in accordance with the Sikep community's way of life.

Sikep children who do not go to formal school still realise the importance of reading and writing. They learn to read from media such as television, their siblings, and various texts on the products they consume everyday. Most Sikep families do not give opportunities to their children to study at formal school. Therefore, when they want to be able to read and write they will find a source of information from outside formal school. If children have older siblings, then they will ask their siblings to teach them how to read and write. The older siblings who are self-taught teach them how to read and write. The children usually learn to read and write from daily experiences they obtain while shopping in the market/stall and watching television programs. The method which relies on television and individual observation is considered inadequate by some Sikep people, therefore, they send their children to Primary School.

The second is a narration on the study locus. The Sikep children who study at formal school have two study locus, namely school and outside school (house, field and farm). Therefore, according to them, both places are their location to learn. As a Sikep child who studies at a formal school, informant "I" has a unique narrative about school.

\section{"Saya kalau pagi diajari oleh orang tua untuk merawat sapi. Setiap pagi saya memberi makan 11 ekor sapi. Sapi-sapi tersebut diberi makan kanggung dicampur dengan saus taucho. Setelah merawat ternak saya berangkat sekolah. Saya suka pelajaran matematika dan kalau sudah besar saya bercita-cita ingin menjadi guru." \\ (In the morning, I am always taught by parents to attend cows. Every morning I feed eleven cows. The cows are given a water spinach meal mixed with special sauces. After attending the cattle, I go to school. I love math and when I am an adult, I want to be a teacher)}

Some of the informants have found it difficult to allocate their time for the two study locus. Most of the children are asked to help harvest in the field, while at the same time they have to study at formal school. Under these circumstances, the children will likely go to the field to help their parents. The dilemma faced by the Sikep children who study at formal 
school is not experienced by the Sikep children who only learn from traditional school. The place of education of Sikep children who do not go to formal school is at home and field/farm owned by their family. Every day they learn about life at home, in the field, and in any other places.

There are differences between the future or dreams of the Sikep children who go to formal school and who do not. As discussed earlier, the Sikep people are farmers. The Sikep people are highly oriented to make their children as farmers in the future to inherit the field and follow all values, teachings and beliefs prevailing in the Sikep community. The narration of the Sikep children who go to formal education suggests that some of the Sikep children's dreams are different from the values of Sikep people. The children dreamed of becoming a pilot, teacher, and police. In the meantime, the Sikep people who do not go to formal school said they still dream of becoming a farmer and that they do not want to choose another profession.

In correlation to the theme of teacher or education, there are basic differences of who becomes the teacher for the group of Sikep children who go to the formal school and who do not. If the Sikep children do not go to formal school, then their parents will become their teachers to teach any knowledge of life including how to become a farmer. The informants acknowledge that they have learned about belief, norm, marriage, farming, and various sciences of life from their parents. As a consequence of the parents' role as teachers, they should adopt a high conversation orientation so that the learning process is carried out effectively (Pramono et al., 2017). Meanwhile, the Sikep children who go to formal school learn not only from their parents but also from their teachers in school. The teachers play an important role in the school because most parents of the Sikep community send their children to formal school only to learn how to read and write. Therefore, many Sikep children did not finish primary school because they stopped going to school after they can read and write. The teacher's capability in comprehending the culture and tradition of the Sikep people could give rich and playful learning experiences for Sikep children.

\section{Teacher's Narration on Sikep Children}

According to de Jong et al. (2018), teachers of ethnic minority children need to reduce the negative reinforcement pattern and increase students' autonomy instead. The teacher has a significant role to enhance the participation of Sikep children who enter formal school. However, it seems that some teachers have a poor understanding of the Sikep culture, therefore, they used stereotypes in judging the Sikep children when they faced the unusual attitudes or unique behaviour of the Sikep children which are different from those of children outside the Sikep community. The following table shows the narration of the teacher towards primary school from the Sikep traditional community.

Table 3: Primary School Teacher Narration towards the Sikep Children who Enter Formal School

\begin{tabular}{ll}
\hline No & Teacher's narratives on Sikep children who join the formal school \\
\hline 1. & Tend to be passive in the class activities \\
2. & Sikep children have to participate in one of the formal religion class \\
3. & Do not have sufficient knowledge about Sikep's way of life \\
4. & Many students from Sikep's community failed to graduate from \\
elementary school
\end{tabular}


Some teachers state that they cannot understand the values held by the Sikep community. They see that the Sikep children are more passive in the classroom and do not have adequate support from their parents. The Sikep children are often absent from school because they must help their parents harvest or plant rice in the field. According to some teachers, the Sikep children tend to be lazy to do their homework. Therefore, they often fail to advance the next grade and graduate from the school. The impression that Sikep children are lazy in school seems to be related to their expectations when they graduate from school. As part of ethnic minorities, they feel they have limited career choices and access to higher education. D'hondt et al. (2016) argue that in terms of educational success the children from minority groups often hampered by limited access and opportunities to be able to pursue higher education.

The teacher's mindset is still looking at the Sikep children from a predominant mindset which caused them to refer to the stereotype without any care to further understand the social and cultural context. Other important considerations that drive rejection from the parents of the Sikep people are an obligation to learn religion. The Sikep people have their own belief/religion which is different from formal religion acknowledged by the government. The obligation to take a religious lesson in school has prompted the parents of Sikep children to ask their children to quit school as soon as they can read and write. The mindset which uses negative stereotype also can be found in the teacher's narration on the Sikep children who are not enrolled in the formal school, as shown in the following table:

\begin{tabular}{ll} 
Table & 4: The teacher's narration on Sikep children who do not enter formal school \\
\hline No & Teacher's narratives on Sikep children who do not go to the formal school \\
\hline 1. & Unruly children \\
2. & Not attending school is a part of Sikep children's destiny \\
3. & Feel sorry to the children who do not go to the formal school \\
4. & Sikep people have different perspectives of education \\
\hline
\end{tabular}

The findings show that some teachers still see the Sikep children who do not enter formal school as uneducated children. They feel pity for the children because they do not go to school like other children. They also judge the children's destiny as a part of the tribe that forbids them to go to school. The teacher's narration signifies a poor understanding of Sikep's education system that narrates education differently. Such poor understanding of the custom and culture of the Sikep people made them less tolerant of the different behaviour of the Sikep children such as being frequently absent from school to help their parents in the field. The Sikep community needs a school that provides a pleasant environment for their children. The school should have a curriculum that takes into account cultural and religious diversity. According to Westheimer (2017), the policymakers who perceive schools as the hope for social transformation and growth need to encompass a multicultural approach in the school curriculum. Students should learn multiple perspectives of thoughts and cultures.

A marginal group such as the children who grew up in a minority group of religion signifies a unique verbal communication to express their social realities. The SCT is the mindset to decrypt the communication of a community (Simmons, 2013). The SCT used in this research observed the Sikep children's communication behavior when they narrated education. The narration of the Sikep children is interpreted to the context, space, and time when a communication event has occurred. Such a communication event in a community can show specific codes on pride, dignity, honour, and restrictions imposed by a community. This 
research is a presentation of speech codes used by the Sikep children to decode the meaning, position, and their expectation in correlation to their current education.

According to Hart (2017), speech codes in a particular society emerge, evolve, and transform through the process of meaning negotiation in daily utterances. The educational narrative in Sikep children signifies speech codes related to educational discourse. The results of this study also indicate that the Sikep children's speech codes regarding education still consider the values of ethnic education important. Three speech codes emerge from the Sikep children's narratives about education: education is a part of everyday life, agriculture is an important skill to learn, and daily behaviour must be seen to comply with the rules and norms of Sikep. Although there are some negotiations on Sikep rules, children still narrate Sikep's rules and beliefs that are important in their lives. In other words, the speech codes regarding education in the Sikep community are closely related to the logic of thinking, the value of spirituality, and the perspective of honor that embedded in the Sikep community.

Sikep children's narratives about education can bring up a learning model that is similar to the homeschooling method with a combined material between local wisdom of the Sikep community and formal school lessons. However, organizing home schooling involves a variety of complex personal and cultural elements. According to Jesse Thomas (2016) numerous things must be considered to conduct home schooling such as parents' perspectives, children's interests, the belief of the community, culture, instructional guidelines, and community resources. When it comes to Sikep community, the obstacle that makes it difficult to apply the concept of combined home schooling is the role of parents as teachers. Sikep parents may well understand the cultural values of the Sikep community but have limitations in teaching the subject matters of formal school such as math and language. The solution to the obstacle is to recruit teachers from outside the Sikep community to teach some formal school lessons needed by Sikep children, especially those related to the latest agricultural innovations. Based on the results of this study, it is hoped that policy makers can create an education system that accommodates the improvement of the Sikep community's welfare, while at the same time appreciating the uniqueness of Sikep education as an important part of the identity of the Sikep group.

\section{CONCLUSION}

The Sikep children's narration on education shows significant codes on the education of the Sikep people. The mindset of the Sikep people asserts that traditional school is highly relevant. They respect moral values and farming culture possessed by their community. The results showed three speech codes that emerge from the children's narratives of education, namely: school is a daily experience, farming skills are important to master and respect the values and rules of the Sikep community. However, Sikep children are exposed to different information and culture. School and media consumption are important factors that made the children have different narrations with the Sikep education concept. Formal school teachers' poor knowledge of the Sikep tradition and culture caused the Sikep children who enter formal school to be alienated from the school environment.

According to Roter (2015), the government or authority must protect the rights of children from minority groups. The protection of minority children's rights includes the opportunity to acquire education, the freedom to learn a particular minority language and to embody a distinct cultural identity (Roter, 2015). Sam Kirkham (2016) identifies three important elements for developing a multicultural sensitive school: 1) multiculturalism-as- 
advantageous assets, (2) practising 'reverse intolerance' in terms of minority groups, and (3) rejection of intolerance and establishing the school as a mindful environment where everybody is living in harmony. Thus, the cooperation between school, local leaders, government administrators, and Sikep parents is necessary to allow for the formulation of the most suitable education model for Sikep children. In other words, it is crucial to build an interculturally sensitive education model (Quinto et al., 2019). An Interculturally sensitive education model will be able to encourage the Sikep community to have a desire to communicate and incorporate formal education materials into their cultural context.

Further studies can be aimed at designing home-schooling methods that include a combination of Sikep cultural materials and formal school materials. Further research can also be developed to examine the educational discourse and pedagogical communication patterns in minority groups in Indonesia including in-depth descriptions of social, economic, and political aspects. Skiba et al. (2015) states that studies of minority groups must be able to provide a comprehensive description of their perspectives and voices.

\section{BIODATA}

Hapsari Dwiningtyas Sulistyani is a lecturer at Communication Department, Faculty of Social and Political Sciences, Diponegoro University. Her research interests are in gender communication, communication and cultural studies, cultural minorities studies, and media studies. Email: hapsarisulistyani@yahoo.com

Turnomo Rahardjo is a lecturer at Communication Department, Faculty of Social and Political Sciences, Diponegoro University. His research interests are in intercultural communication, cultural communication, media literacy, and minorities studies. Email: turnomorahardjo@gmail.com

Lintang Ratri Rahmiaji is a lecturer at Communication Department, Faculty of Social and Political Sciences, Diponegoro University. Her research interests are in journalism, children and media consumption, and media literacy. Email: lintangratri84@gmail.com

Taufik Suprihatini is a lecturer at Communication Department, Faculty of Social and Political Sciences, Diponegoro University. Her research interests are in intercultural communication, cultural communication, and minorities studies. Email: taufik_fspkom@yahoo.com 


\section{REFERENCES}

Aoki, E. (2000). Mexican American ethnicity in Biola, CA: An ethnographic account of hard work, family, and religion. The Howard Journal of Communications, 11 (3), 207-227.

Alamsyah (2015). Eksistensi dan Nilai-nilai Kearifan Komunitas Samin di Kudus dan Pati. Humanika, 21(1), 63-74.

Chase, S. E. (2018). Narrative Inquiry: Toward Theoretical and Methodological Maturity. In N. K. Denzin \& Y. S. Lincoln (Eds.), The SAGE Handbook of Qualitative Research (5 $5^{\text {th }}$ Ed.). Los Angles: Sage Publications.

Carbaugh, D. (2008). Culture in Conversation. London: Taylor \& Francis e-Library.

Chornet, D., \& Parr, B. (2017). Situations in intercultural communication: A six-step iterative training cycle. Journal of Intercultural Communication; Göteborg, 43.

Darmastuti, R., Bajari, A., Martodirdjo, H. S., \& Maryani, E. (2016). Gethok tular, pola komunikasi gerakan sosial berbasis kearifan lokal mayarakat Sikep di Sukolilo. Jurnal ASPIKOM, 3(1).

de Jong, E. M., Koomen, H. M. Y., Jellesma, F. C., \& Roorda, D. L. (2018). Teacher and child perceptions of relationship quality and ethnic minority children's behavioral adjustment in upper elementary school: A cross-lagged approach. Journal of School Psychology, 70, 27-43. https://doi.org/10.1016/j.jsp.2018.06.003

D'hondt, F., Praag, L. V., Houtte, M. V., \& Stevens, P. A. J. (2016). The attitude-achievement paradox in Belgium: An examination of school attitudes of ethnic minority students. Acta Sociologica, 59(3), 215-231.

Hart, T. (2017). Speech codes theory. In Y.Y. Kim (Ed.), The international encyclopedia of intercultural communication. Wiley Online Library. https://doi.org/10.1002/9781118783665.ieicc0123

Jong, E. M., Koomen, H. M. Y., Jellesma, F. C., \& Roorda, D. L. (2018). Teacher and child perceptions of relationship quality and ethnic minority children's behavioural adjustment in upper elementary school: A cross-lagged approach. Journal of School Psychology, 70, 27-43.

Kennedy, K. J., \& Hue, M. K. (2011). Researching ethnic minority students in a Chinese context: Mixed methods design for cross cultural understandings. Comparative Education, 47(3: Educational Research in Confucian Heritage Cultures), 343-354. https://doi.org/10.1080/03050068.2011.586766

Kim, M., \& Covino, K. (2015). When stories don't make sense: Alternative ways to assess young children's narratives in social contexts. The Reading Teacher, 68(5), 357-361.

King, L. J. (2015). A narrative to the colored children in America: Lelia Amos Pendleton, African American history textbooks, and challenging personhood. The Journal of Negro Education, 84(4), Special Focus: Historical Narratives and Race Relations with Implications for African American Males and Faculty in Education, 519-533. https://doi.org/10.7709/jnegroeducation.84.4.0519

Kirkham, S. (2016). Constructing multiculturalism at school. Discourse \& Society, 27(4), 383400.

Madison, D. S. (2020). Critical ethnography: Method, ethics, and performance (3rd ed.). Thousand Oaks: Sage Publications.

Meon, P.-G., \& Tojerow, I. (2019). The minority ethic: Rethinking religious denominations, minority, status, and educational achievement across the globe. Journal of Comparative Economics, 47, 196-214. 
Miller, K. (2005). Communication Theories: Prespectives, Processes, and Contexts (2 ed.). Singapore: McGraw-Hill.

Patton, M. Q. (2002). Qualitative research and evaluation methods (3rd ed.). California: Sage Publication.

Pramono, F., Lubis, D. P., Puspitawati, H., \& Susanto, D. (2017). Communication pattern and family typology of high school adolescent in Bogor - West Java. Jurnal Komunikasi Ikatan Sarjana IImu Komunikasi Indonesia, 2(1), 20-26.

Quinto, E. J. M., Ofalia, B. C., Bae, J., \& Salonga L. S. B. (2019). (Un)willingness to communicate in English among Korean study aboard student in the Philippines. Jurnal Komunikasi: Malaysian Journal of Communication, 35(4), 17-31.

Rasna W. I., \& Tantra D. K. (2017) Reconstruction of local wisdom for character education through the Indonesia language learning: An ethno-pedagogical methodology. Theory and Practice in Language Studies, 7(2), 1229-1235.

Rosyid, M. (2010). Perkawinan masyarakat sikep dalam pandangan hukum negara. Jurnal Analisa, XVII(1), 229-244.

Roter, P. (2015). Minority children and education in the work of the advisory committee. International Journal on Minority and Group Rights, 22(2), 202-231.

Shaw, J. (2017). Thinking with stories: A renewed call for narrative inquiry as a social work epistemology and methodology. Canadian Social Work Review / Revue Canadienne de Service Social, 34(2), 207-227.

Simmons, N. (2013). Speaking like a queen in RuPaul's drag race: Towards a speech code of American drag Queens. Sexuality \& Culture, 18, 630-648.

Skiba, R. J., Artiles, A. J., Kozleski, E., B., Losen D. J., \& Harry, E. G. (2016). Risks and consequences of oversimplifying educational inequities: A response to Morganet al. Educational Researcher, 45(3), 221-225.

Steinberg, S. R. (2014). Critical constructivism. In D. Coghlan \& M. Brydon-Miller (Eds.), The SAGE encyclopedia of action research (Vol. 1, pp. 203-206). Thousand Oaks: SAGE.

Thomas, J. (2016). Instructional motivations: What can we learn from homeschooling families? The Qualitative Report, 21(11), 2073-2086.

Westheimer, J. (2017). Education that matters. Canadian Journal of Education/ Revue Canadienne de l'éducation, 40(2), 1-15. 